\title{
EFEKTIVITAS STERILISASI METODE PANAS KERING PADA ALAT MEDIS RUANG PERAWATAN LUKA RUMAH SAKIT Dr. H. SOEMARNO SOSROATMODJO KUALA KAPUAS
}

\author{
Raudah, Tien Zubaidah, Imam Santoso \\ Poltekkes Kemenkes Banjarmasin Jurusan Kesehatan Lingkungan \\ Jl.H.M.Cokrokusumo No.1A Kota Banjarbaru 70714 \\ E-mail: raudah.auda@yahoo.com
}

\begin{abstract}
Effectiveness Of Sterilization Method of Dry Heat At The Wound Care Medical Devices Hospital Room Dr. H. Soemarno Sosroatmodjo Kuala Kapuas. Hospital Dr. H. Soemarno Sosroatmodjo is a Type C hospitals that provide 24-hour medical services.Bed capacity of 145 with the number BOR (Bed Occupancy Rate) 51.36\%.Efforts to prevent the occurrence of nosocomial infections from medical devices one of which is the process of sterilization with dry heat heating process.The purpose of this study was to determine the effectiveness of dry heat sterilization methods on medical devices in the Hospital Dr. H. Soemarno Sosroatmodjo. This type of research is quasi-experimental.Type variables used are the independent variables (temperature variation with the dry heat oven), the dependent variable (number of bacteria).Samples taken medication is a tool set consisting of a pair of tweezers and tub instruments. Analysis of data use Oneway Anova test. Based on the results of the examination, in the highest number of bacteria known medical tool tweezers is the average number of bacteria colonies $1.33 / \mathrm{cm}$ at $125^{\circ} \mathrm{C}$, and the highest number of bacteria of medical tools like instrument that is the average number of bacteria colonies $0.66 / \mathrm{cm}$ at the temperature of $125^{\circ} \mathrm{C}$. Statistical data analysis for medical devices tweezers with Oneway Anova test, after sterilized generate significant value of 0.09 , which sig> 0.05 so that Ho is accepted, meaning there is no significant difference and statistical analysis for medical devices like instrument with Oneway Anova test produces the significant value of 0.40 , which sig $>0.05$ means that there is no significant difference.
\end{abstract}

Keywords: Hospitals; medical device; numbers germs; sterilization.

\begin{abstract}
Abstrak: Efektivitas Sterilisasi Metode Panas Kering Pada Alat Medis Ruang Perawatan Luka Rumah Sakit Dr. H. Soemarno Sosroatmodjo Kuala Kapuas. Rumah Sakit Dr. H. Soemarno Sosroatmodjo adalah rumah sakitType C yang memberikan pelayanan medis 24 jam. Kapasitas tempat tidur sebanyak 145 dengan angka BOR (Bed Occupancy Rate) 51,36\%. Upaya mencegah terjadinya infeksi nosokomial dari alat medis salah satunyayaitu dengan proses sterilisasi dengan proses pemanasan panas kering. Tujuan penelitian ini adalah untuk mengetahui efektifitas sterilisasi metode panas kering pada alat medis di Rumah Sakit Dr. H. Soemarno Sosroatmodjo. Jenis penelitian yang digunakan adalah quasieksperimen. Jenis variabel yang digunakan yaitu variabel bebas (Variasi suhu pemanasan kering dengan oven), variabel terikat (angka kuman). Sampel yang diambil yaitu alat set medikasi yang terdiri dari pinset dan bak instrumen. Analisis data menggunakan uji Oneway Anova. Berdasarkan hasil pemeriksaan, diketahui angka kuman tertinggi alat medis pinset yaitu dengan rata-rata angka kuman $1,33 \mathrm{koloni} / \mathrm{cm}$ pada $125^{\circ} \mathrm{C}$, dan angka kuman tertinggi alat medis bak instrumen yaitu dengan rata-rata angka kuman 0,66 koloni/cm pada suhu $125^{\circ} \mathrm{C}$. Analisis data statistik untuk alat medis pinset dengan uji Oneway Anova, sesudah disterilisasi menghasilkan nilai signifikasi 0,09,dimana sig $>0,05$ sehingga Ho diterima, artinya tidak ada perbedaan yang signifikan dan analisis data statistik untuk alat medis bak instrumen dengan uji Oneway Anova menghasilkan nilai signifikan 0,40, dimana sig $>0,05$ artinya tidak ada perbedaan yang signifikan.
\end{abstract}

Kata Kunci: Rumah sakit; alat medis; angka kuman; sterilisasi. 


\section{PENDAHULUAN}

Sterilisasi dalam pengertian medis merupakan proses dengan metode tertentu dapat memberikan hasil akhir, yaitu suatu bentuk keadaan yang tidak dapat ditunjukkan lagi adanya mikroorganisme strerilisasi cukup banyak. Metode sterilisasi cukup banyak, namun alternatif yang dipilih sangat bergantuk pada keadaan serta kebutuhan setempat.Apapun pilihan metodenya, hendaknya tetap menjaga kualitas hasil sterilisasi [1].

Semua alat kesehatan yang kontak langsung dengan pasien dapat menjadi sumber infeksi, oleh karena itu persediaan dari barang steril cukup memainkan peran penting dalam mengurangi penyebaran penyakitdalam pelayanan kesehatan [2].

Infeksi ini juga dapatterjadi pada pasien yang umumnya selalu berpindahpindah dan wakturawat di rumah sakit lebih pendek, pasien sering dipulangkan sebeluminfeksi ini menjadi nyata atau timbul gejala.Kenyataannya sebagian besarinfeksi nosokomial pada pasien rawat inap dan rawat jalan menjadi nyatasetelah mereka pulang.Di negara berkembang, infeksi ini jauh lebih tinggi,karena kurangnya pengawasan, praktik pencegahan infeksi yang buruk,pemakaian sumber terbatas yang tidak tepat dan rumah sakit yang penuhsesak [3].

Infeksi nosokomial dikenal pertama kali pada tahun 1847 oleh Semmelweis dan hingga saat ini tetap menjadi masalah yang cukup menyita perhatian. Angka infeksi nosokomial yang tercatat dibeberapa Negara berkisar antara 3,3\% $9,2 \%$, artinya sekian persen penderita yang dirawat tertular infeksi nosokomial dan dapat terjadi secara akut atau secara kronis [4].

Suatu penelitian infeksi nosokomial di rumah sakit khusus penyakit menular diJakarta menunjukkan, dari 723 pasien, didapatkan 191 (26,4\%) pasien dengan 285 infeksi menurut lokasi anatomi. Dari 285 infeksi, tingkatinfeksi nosokomial tertinggi adalah infeksi saluran kemih $(15,9 \%)$, diikutiinfeksi bakteri $(10,8 \%)$,
$\%)$, infeksi saluran pencernaan $(2,6 \%)$, infeksi kulit $(2,4 \%)$, infeksi selaput lendir oral $(1,4 \%)$, infeksi jarum infus dan tingkat terendah adalah infeksi saluranpernapasan atas $(0,6 \%)$ [5].

Data pada tahun 2014 jumlah rumah sakit di Kalimantan Selatan berjumlah 32 [6]. Angka kejadian infeksi saluran kemih berdasarkan data RSUD Ulin Banjarmasin, Kalimantan Selatan pada pasien rawat inap di bangsal penyakit dalam mengalami peningkatan dari tahun ke tahun yaitu pada tahun 2008 adalah 113 pasien dan pada tahun 2009 adalah 143 pasien.

Namun data tersebut secara umumnya di akibatkan oleh lingkungan rumah sakit, dan belum diteliti secara komplek apakah diakibatkan oleh alat medis satau faktor lainnya, karena belum adanya penelitian yang mengkhususkan atau secara detail meneliti tentang keterkaitan alat medis terhadap penyakit infeksi nosokomial di rumah sakit.Infeksi nosokomial disebabkan oleh beberapa faktor luar salah satunya adalah melalui peralatan medis. Rumah sakit diharuskan untuk selalu memperhatikan kondisi peralatan medis yang memenuhi standar dengan proses sterilisasi agar alat medis terbebas dari seluruh mikroorganisme atau patogen penyebab penyakit. Metode sterilisasi cukup banyak, namun alternatif yang dipilih sangat bergantung pada keadaan serta kebutuhan setempat [4].

$$
\text { Data pada tahun } 2014
$$
menunjukkan rumah sakit di provinsi Kalimantan Tengah berjumlah 19 rumah sakit [7]. Di Kabupaten Kuala Kapuas memiliki Rumah Sakit Umum Daerah Dr. H. Soemarno Sosroatmodjo yang telah lama berdiri sejak tahun 1939, merupakan rumah sakit tipe $\mathrm{C}$, dengan jumlah pasien yang selalu meningkat dari tahun ketahun. Peningkatan tersebut terlihat pada pasien yang melakukan operasi pada 3 tahun terakhir mengalami peningkatan yaitu pada tahun 2013 berjumlah 1.247 pasien, tahun 2014 berjumlah 1.306 pasien dan tahun 2015 berjumlah 1.297 pasien.Peningkatan pasien operasi ini diprediksi mempunyai risiko terjadinya infeksi nosokomial yang 
dimana faktor penyebab infeksi salah satunya dapat melalui alat medis.Data pada tahun 2012 RSUD Dr. H. Soemarno Sosroatmodjo Kuala Kapuas, jumlah penyakit infeksi saluran kemih berjumlah 222 kasus. Pada tahun 2015 jumlah infeksi pada masa perinatal berjumlah 9 kasus.

RSUD tersebut melakukan sterilisasi dengan metode panas kering dengan suhu $130^{\circ} \mathrm{C}$ selama 30 menit. Metode panas kering selalu digunakan dalam sterilisasi alat medis untuk operasi ataupun pada saat proses perawatan. Sterilisasi panas kering prinsip dasarnya melalui mekanisme konduksi, panas akan diabsorpsi oleh permukaan luar dari peralatan yanag akan disterilkan, lalu merambat kebagian yang lebih dalam dari peralatan [4]. Berdasarkan latar belakang di atas, perlu dilakukan penelitian, agar dapat dibuktikan apakah sterilisasi menggunakan tehnik panas kering dalam menghilangkan angka kuman pada alat medis tersebut memenuhi standar Kepmenkes RI No: 1204/MENKES/SK/2004 yaitu pada alat medis harus bebas kuman TPC (0).

Secara umum penelitian ini bertujuan untuk mengetahui efektivitas sterilisasimetode panas kering pada alat medis ruang perawatan luka rumah sakit Dr. H. Soemarno Sosroatmodjo, mengetahuiangka kuman(TPC) alat medis ruang perawatan luka setelah disterilisasi dengamn suhu $125^{\circ} \mathrm{C}$ di RSUD Dr. H. Soemarno Sostroatmodjo Kuala Kapuas, mengetahui angka kuman (TPC) alat medis ruang perawatan luka setelah disterilisasi dengan suhu $130^{\circ} \mathrm{C}$ di RSUD Dr. H. Soemarno Sostroatmodjo Kuala Kapuas, mengetahui angka kuman (TPC) alat medis ruang perawatan luka setelah disterilisasi dengan suhu $135^{\circ} \mathrm{C}$ di RSUD Dr. H. Soemarno Sosroatmodjo Kuala Kapuas, dan menganalisis perbandingan angka kuman (TPC) alat medis ruang perawatan luka setelah disterilisasi dengan suhu $125^{\circ} \mathrm{C}, 130^{\circ} \mathrm{C}$ dan $135^{\circ} \mathrm{C}$ di RSUD Dr. H. Soemarno Sosroatmodjo Kuala Kapuas.

\section{BAHAN DAN CARA PENELITIAN}

Desain penelitian yang digunakan yaitu Posttest Design [8]. Karena adanya pemeriksaan angka kuman TPC setelah di sterilisasi dengan suhu $125^{\circ} \mathrm{C}, 130^{\circ} \mathrm{C}$ dan $135^{\circ} \mathrm{C}$. Adapun desain penelitian dapat di gambarkan sebagai berikut. Populasi pada penelitian ini adalah semua alat medis pinset dan bak instrument di RSUD Dr. H. Soemarno Sosroatmodjo Kuala Kapuas. Yang men jadi variabel penelitian ini adalah variabel bebas yaitu Suhu panas kering (Oven), $125^{\circ} \mathrm{C}$ selama 35 menit, $130^{\circ} \mathrm{C}$ selama 30 menit, $135^{\circ} \mathrm{C}$ selama 25 menit. Variabel terikat yaitu Angka kuman (TPC). Perhitungan yang diteliti adalah tentang angka kuman pada alat medis. Metode pengumpulan data yaitu data umum dan data khusus, data umum meliputi gambaran umum rumah sakit Dr. H. Soemarno Sosroatmodjo Kuala Kapuas. Data khusus yaitu hasil angka kuman sterilisasi dengan suhu $125^{\circ} \mathrm{C}, 130^{\circ} \mathrm{C}$ dan $135^{\circ} \mathrm{C}$ pada alat medis ruang perawatan luka rumah sakit. Sumber data terdiri dari data primer dan data sekunder, data primer adalah hasil pengukuran usap alat medis di ruang perawatan, data sekunder meliputi data umum dan hasil wawancara dengan petugas/pihak rumah sakit.Cara pengumpulan data yaitu dengan menyalin data umum rumah sakit sesuai dengan keperluan peneliti dan melakukan pemeriksaan laboratorium dengan usap alat sesudah di sterilisasi. Pengolahan data yaitu menggunakan analisis uji Oneway Anova.

\section{HASIL PENELITIAN DAN PEMBAHASAN}

Hasil pengukuran angka kuman usap alat pada alat medis pinset ruang perawatan luka rumah sakit Dr. H. Soemarno Sosroatmodjo Kuala kapaus pada Tabel 1. 
Tabel 1. Angka Kuman (TPC) Pada Alat Medis Pinset

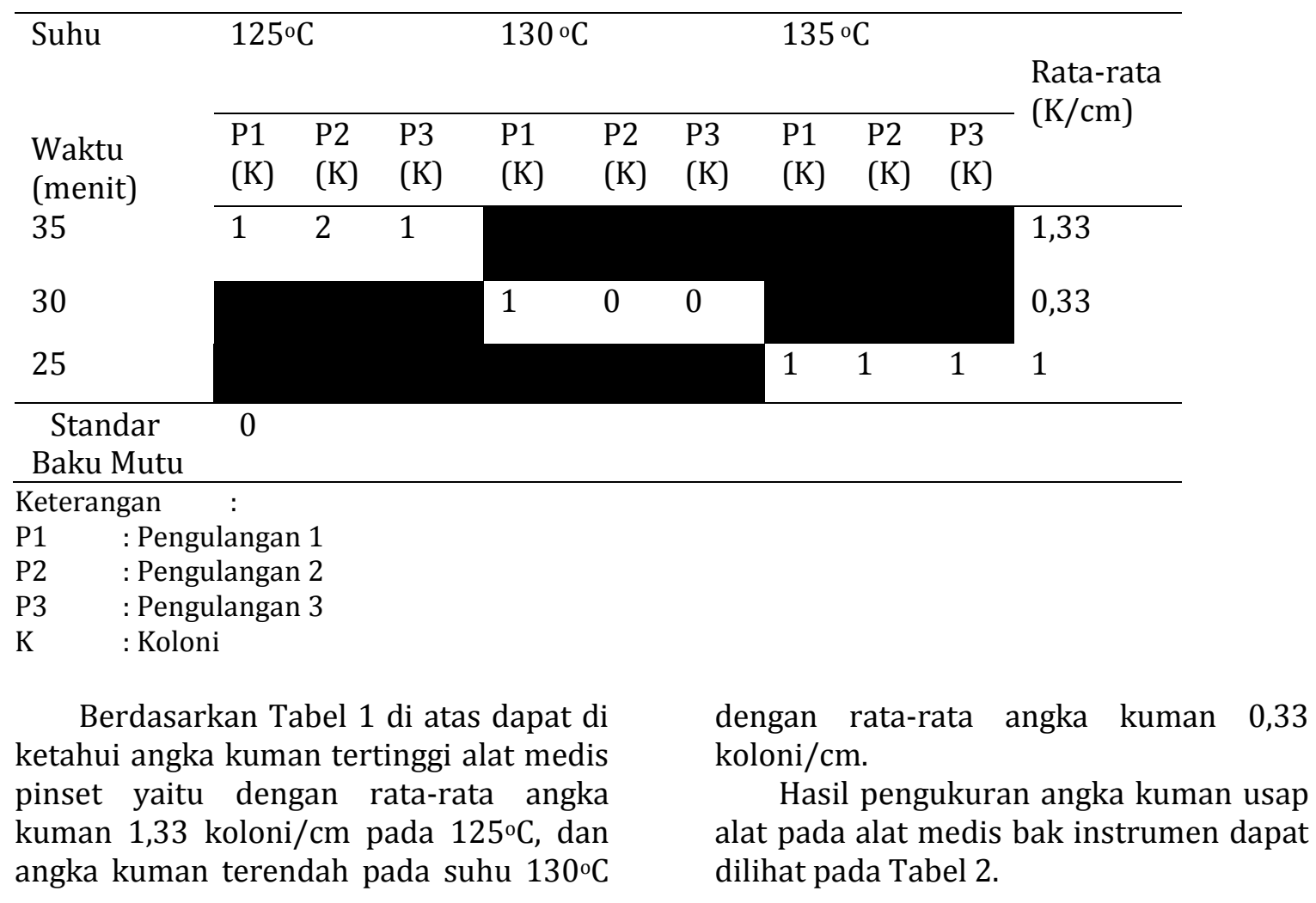

Tabel 2. Angka Kuman (TPC) Pada Alat Medis Bak Instrumen

\begin{tabular}{|c|c|c|c|c|c|c|c|c|c|c|}
\hline \multirow{2}{*}{$\begin{array}{l}\text { Suhu } \\
\text { Waktu } \\
\text { (menit) }\end{array}$} & \multicolumn{3}{|c|}{$125^{\circ} \mathrm{C}$} & \multicolumn{3}{|c|}{$130^{\circ} \mathrm{C}$} & \multicolumn{3}{|c|}{$135^{\circ} \mathrm{C}$} & \multirow{2}{*}{$\begin{array}{l}\text { Rata-rata } \\
(\mathrm{K})\end{array}$} \\
\hline & $\begin{array}{l}\mathrm{P} 1 \\
(\mathrm{~K})\end{array}$ & $\begin{array}{l}\text { P2 } \\
\text { (K) }\end{array}$ & $\begin{array}{l}\text { P3 } \\
\text { (K) }\end{array}$ & $\begin{array}{l}\text { P1 } \\
\text { (K) }\end{array}$ & $\begin{array}{l}\text { P2 } \\
\text { (K) }\end{array}$ & $\begin{array}{l}\text { P3 } \\
\text { (K) }\end{array}$ & $\begin{array}{l}\text { P1 } \\
\text { (K) }\end{array}$ & $\begin{array}{l}\text { P2 } \\
\text { (K) }\end{array}$ & $\begin{array}{l}\text { P3 } \\
\text { (K) }\end{array}$ & \\
\hline 35 & 1 & 0 & 1 & & & & & & & 0,66 \\
\hline 30 & & & & 0 & 0 & 0 & & & & 0 \\
\hline 25 & & & & & & & 0 & 1 & 0 & 0,33 \\
\hline $\begin{array}{l}\text { Standar } \\
\text { Baku Mutu }\end{array}$ & 0 & & & & & & & & & \\
\hline \begin{tabular}{ll}
\multicolumn{2}{l}{ Keterangan } \\
P1 & :Pen \\
P2 & : Pen \\
P3 & :Pen \\
K & : Kol
\end{tabular} & $\begin{array}{l}\text { : } \\
\text { ulang } \\
\text { ulang } \\
\text { ulang } \\
\text { ni }\end{array}$ & & & & & & & & & \\
\hline
\end{tabular}

Berdasarkan Tabel 2 di atas dapat diketahui angka kuman tertinggi alat medis bak instrumen yaitu dengan ratarata angka kuman 0,66 koloni/cm pada suhu $125^{\circ} \mathrm{C}$, dan angka kuman terendah pada suhu $130^{\circ} \mathrm{C}$ dengan rata-rata angka kuman 0 koloni/cm.

Asumsi uji anova antara lain data harus homogen, setelah dilakukannya uji homogenitas, pada kolom smirnov 
didapatkan nilai $\mathrm{p}=0,200$, artinya data homogen, sehingga uji Anova bisa dilakukan untuk analisis uji bivariat.
Data hasil analisis statistik menggunakan uji One Way Anova untuk alat medis pinset dilihat pada Tabel 3 .

Tabel 3. Hasil Statistik Untuk Alat Medis Pinset

\begin{tabular}{|c|c|c|c|c|}
\hline No & Variasi Suhu dan Waktu & $\mathbf{N}$ & Mean & Sig \\
\hline 1 & $125^{\circ} \mathrm{C} " 35$ menit & 3 & 1,33 & \\
\hline 2 & $130^{\circ} \mathrm{C} " 30$ menit & 3 & 0,33 & 0,09 \\
\hline 3 & $135^{\circ} \mathrm{C} " 25$ menit & 3 & 1 & \\
\hline
\end{tabular}

Hasil uji analisis statistik One Way Anovauntuk alat medis pinset dengan tingkat signifikan $5 \%(0,05$ diperoleh nilai $\mathrm{p}=0,09$ karena $p$-value 0,09>0,05 maka Ho diterima dan Ha ditolak, yang artinya tidak ada perbedaan antara angka kuman setelah disterilisasi dengan suhu $125^{\circ} \mathrm{C}, 130^{\circ} \mathrm{C}, 135^{\circ} \mathrm{C}$.

Data hasil analisis statistik menggunakan uji One Way Anova untuk alat medis bak instrumen dapat dilihat pada Tabel 4.

Tabel 4. Hasil Statistik Untuk Alat Medis Bak Instrumen

\begin{tabular}{lllll}
\hline No & Variasi Suhu dan Waktu & N & Mean & Sig \\
\hline 1 & $125^{\circ} \mathrm{C}$ " 35 menit & 3 & 0,61 & \\
2 & $130^{\circ} \mathrm{C}$ " 30 menit & 3 & 0 & 0,40 \\
3 & $135^{\circ} \mathrm{C}$ " 25 menit & 3 & 0,33 & \\
\hline
\end{tabular}

Hasil uji analisis statistik One Way Anovauntuk alat medis bak instrumen dengan tingkat signifikan $5 \% \quad(0,05$ diperoleh nilai $\mathrm{p}=0,40$ karena $p$-value

\section{KESIMPULAN DAN SARAN}

Untuk alat medis pinset rata-rata angka kuman pada suhu $125^{\circ} \mathrm{C}$ yaitu 1,33 koloni/cm dengan angka kuman tertinggi pada pengulangan 2 (dua) yaitu 2 koloni/cm. Untuk suhu $130^{\circ} \mathrm{C}$ diperoleh angka kuman terendah pada pengulangan 1 dan 2 yaitu dengan angka kuman 0 koloni/cm, dan pada suhu $135^{\circ} \mathrm{C}$ diperoleh rata-rata angka kuman 1 koloni/cm. Angka kuman pada alat medis bak instrumen untuk suhu $125^{\circ} \mathrm{C}$ rata-rata angka kuman 0,66 koloni/cm, untuk suhu $130^{\circ} \mathrm{C}$ diperoleh rata-rata angka kuman 0 koloni/cm, dan pada suhu $135^{\circ} \mathrm{C}$ diperoleh rata-rata angka kuman 0,33 koloni/cm.Variasi suhu yang diteliti hanya satu suhu memenuhi baku mutu yaitu suhu $130^{\circ} \mathrm{C}$ dengan angka kuman 0 koloni/cm untuk sterilisasi alat medis bak instrumen.Secara statistik dinyatakan
0,40> 0,05 maka Ho diterima dan Ha ditolak, yang artinya tidak ada perbedaan antara angka kuman setelah disterilisasi antara suhu $125^{\circ} \mathrm{C}, 130^{\circ} \mathrm{Cdan}$ suhu $135^{\circ} \mathrm{C}$. tidak ada perbedaan yang bermakna angka kuman setelah disterilisasi menggunakan suhu $125^{\circ} \mathrm{C}$, suhu $130^{\circ} \mathrm{C}$, dan suhu $135^{\circ} \mathrm{C}$.

Dapat disarankan bagi petugas instalasi Central Supply Departement (CSSD) selalu menggunakan alat pelindung diri yang lengkap untuk mencegah terjadinya infeksi nosokomial dari alat set medikasi tersebut kepada petugas sterilisasi.

\section{KEPUSTAKAAN}

1. Darmadi, 2008. Infeksi Nosokomial Problematika, dan Pengendaliannya. SalembaMedika. Jakarta.

2. Hartono, 1985. Mengenal Alat-alat Kesehatandan Kedokteran. Jakarta

3. Tietjen, L, dkk. 2004. Panduan Pencegahan Infeksi untuk Fasilitas Pelayanan Kesehatan dengan Sumber 
Daya Terbatas. Yayasan Bina Pustaka Sarwono Prawirohardjo. Jakarta

4. Darmadi, 2008. Infeksi Nosokomial Problematika, dan Pengendaliannya. SalembaMedika. Jakarta.

5. Janas dkk, 1992. Infeksi Saluran Kemih. Jurnal Kesehatan. Jakarta

6. BPS, 2015. KalimantanSelatan Dalam Angka. Banjarbaru.
7. Departemen Kesehatan RI. 2009. Pedoman Instalasi Pusat Sterilisasi (Central Sterile Supply Department/CSSD) Di Rumah Sakit. DepKes RI. Jakarta.

8. Hidayat, 2009. Metode Penelitian Keperawatan dan Teknik Analisis Data. Salemba Medika. Jakarta. 